\title{
TEOLOGIESE BEGRONDING IN DIE NA-OORLOGSE ONTWIKKEIING IN DIE GEREFORMEERDE KERK VAN SUID-AFRIKA
}

\author{
Prof. G. P. L. v.d. Linde
}

In hierdie hoofstuk moet „Die Teologiese begronding van standpunte" in die na-oorlogse ontwikkeling van die Gereformeerde Kerk in Suid-Afrika, blootgelê word.

\section{WAT IS TEOLOGIE ?}

Soos bekend is op hierdie vraag deur die eeue verskillende antwoorde gegee wat tog uiteindelik maar daarop neerkom dat dit in die teologie gaan om die kennis van God. Dan sou God die objek van die teologie wees. Tereg vra Douma (J. Douma (1971) Oriëntatie in de Theologie. De Vuurbraak, p. 8): „Kunnen wij wel wetenschappelijke studie maken van God?" By alles wat ook die Gereformeerde teoloë oor die objek van die teologie te sê het, staan dit ook weer vas dat ons God alleen ken in soverre Hy Hom geopenbaar het. Hy maak Homself, soos bely word in artikel 2 N.G.B., bekend deur twee middele: sy werke, en nog duideliker en nader volkome bekend deur sy heilige en goddelike Woord, soveel naamlik as wat ons nodig het in hierdie lewe, tot sy eer en die saligheid van wie aan Hom behoort. Die werke van God in ,die skepping, onderhouding en regering van die hele wêreld" kan egter nie deur die gevalle mens geken word nie tensy hy alles sien deur die bril van die besondere openbaring: die Heilige Skrif (vgl. Calvyn Institusie I.VI. 1 p. 37 - Vertaling A. Sizoo). Die teologie is dan die wetenskap wat die besondere openbaring van God soos vervat in die Heilige Skrif as veld het (vgl. Douma p. 11 en 16).

Wanneer die ,teologiese begronding van standpunte in die naoorlogse ontwikkeling van die Gereformeerde Kerk in Suid-Afrika" blootgelê word, beteken dit dat die standpunte as het ware voor Gods aangesig geplaas moet word. En dit kan ons op geen ander wyse doen as om te vra of die uitgangspunt by die formulering van en die geformuleerde standpunt self, die wil van God, soos $\mathrm{Hy}$ dit geopenbaar het in sy Woord ,is nie.

Daarby moet onthou word dat die belydenis vir ons in alles ooreenkom met die Heilige Skrif. Wanneer die Heilige Skrif dus aangelê word as maatstaf by die geskiedenisse van die kerk sluit dit vir die gereformeerde vanselfsprekend die aanvaarde Belydenisskrifte in.

Die opdrag hou dus in dat die na-oorlogse ontwikkeling van die Gereformeerde Kerk in Suid-Afrika beskryf en aan die Heilige Skrif en die Belydenisskrifte getoets moet word.

Die volledige uitvoering van die opdrag sou egter baie meer tyd en ruimte in die geheel opset van die voordrag in beslag neem, as wat daarvoor ingeruim is. Daarom word dit beperk tot die aanduiding van standpunte wat ingeneem is en of dit gerugsteun word 
deur Skrif en belydenisgronde. Op die juistheid van die beroep op Skrif en belydenis sal egter hier nie ingegaan kan word nie.

'n Verdere beperking wat noodwendig opgelê moet word raak die veld van ondersoek. Dit is wetenskaplik alleen verantwoord om oor die ontwikkeling van die Gereformeerde Kerk in S.A. te spreek indien alles, vanaf dit wat in die plaaslike kerke tot in elke gemeenskaplike beraad en/of optrede van die kerke gebeur het, onder oë gesien word. Uiteraard was so 'n ondersoek met die oog op hierdie samekoms nie moontlik nie en is alleen aandag gegee aan die belangrikste aspekte van die gesamentlike optrede van die kerke in sinode byeen.

\section{KRISIS AAN TEOLOGIESE SKOOL 1945}

Die eerste na-oorlogse sinode, Potchefstroom 1945, is oorheers deur die „moeilikhede aan die Teologiese Skool", wat rondom uitsprake van prof. dr. C. J. H. de Wet sentreer het. Vrae het ontstaan insake sy leer aangaande die leerstuk van die Filioque. Hy sou geleer het, strydig met die N.G.B. art. 8 en 11, Nicea en Athanasius, dat (1) die Heilige Gees alleen van die Vader uitgaan en nie ook van die Seun nie; (2) dat t.o.v. die nature van Christus strydig met die N.G.B. art. 19 en H.K., Sondag ...., in Christus twee persone en een wese is; (3) dat t.o.v. die verkiesing en verwerping die Heilige Skrif geen ,direkte bewyse vir 'n ewige verkiesing en verwerping gee nie...." wat strydig met Dordtse leerreëls c.1 en art. 16 N.G.B. sou wees; (4) dat die erfsonde nie ,deur God toegereken word in die weg van die verbond nie", strydig met C.3 en 4 Dordtse leerreëls en art. 15 N.G.B. en Sondag 3 H.K.; (5) dat die gesag van die Belydenisskrifte twyfelagtig is; (6) dat Job (strydig met die Skrif) eers op die ashoop wedergebore is; (7) dat Jakob by Bet-el die Here as 'n lokale Here beskou het; (8) dat Melgisedek nie priester van die Ware God was nie; (9) dat die kerk gedagtes geopenbaar het wat strydig sou wees met die Openlike Verklaring van die Gereformeerde Kerk en N.G.B. art. 27-29. (Handelinge 1945; p. 56 en 57).

Die Sinode het op hierdie klagte van die Kuratorium deeglik ingegaan en bevind dat dit wat prof. de Wet geleer en geskryf het in stryd is met die Skrif en Belydenis. Hy het sy instemming met die Belydenis betuig en sy spyt uitgespreek. Die sinode was daarmee nie tevrede nie en het aan hom 'n bedenktyd van drie maande gegee waarna hy ,'n skriftelike verklaring sal doen voor die Kuratorium, waarna die Kuratorium volgens gegewe sinodale mandaat verder as gevolmagtigdes van die Generale Sinode sal optree" (Handelinge 1945, p. 201).

Die Kuratore kon geen oplossing in die saak vind nie. Daar het op 6 Februarie 1946 'n ,buitengewone generale sinode" byeengekom. Terwyl die saak nog onder behandeling was, het prof. de Wet bedank as professor aan die Teologiese Skool sowel as lidmaat van die Gereformeerde Kerk. Die Sinode verklaar daarna: „Aan die einde van 'n lang en sorgelike leerstryd wil die Gereformeerde Kerk opnuut bely dat hy staan op die grondslag van die 
Heilige Skrif as die onfeilbare Woord van God, dat hy van harte die Drie formuliere van eenheid omhels en wel in die letterlike en historiese sin, terwyl hy aanneem dat alles in hierdie belydenisskrifte ooreenkom met die Woord van God, solank as die teendeel voor die bevoegde kerklike vergaderinge nie bewys is nie" (Handelinge 1946, p. 62).

SINODE 1945 OOR STAATSLOTERY, KOMMUNISME EN RASSEVERHOUDINGE

Die Sinode van 1945 het ook opnuut standpunt ingeneem teen 'n staatslotery. Op die aandrang van groepe in die land vir 'n staatslotery doen die Sinode 'n beroep op die owerheid om nie te swig voor die druk nie omdat die Woord van God beveel „dat ons in die sweet van ons a angesig ons brood moet eet.... Dit druis in teen die Woord van God om onsself te werp in die arms van die avontuur. Lotery is ' $n$ misbruik van die Naam van die Here en druis in teen die derde gebod van die Wet.... Die lot van verdeling is in die Heilige Skrif 'n godsdienstige handeling" (Handelinge 1945 , p. 64).

Die sake van die dag wat die aandag verg vind ook 'n neerslag in besluite wat die Sinode (1945) geneem het.

Daar word aangedring op die bestryding van die kommunisme. Die kommunisme is ,in lewens en wêreldbeskouing wat God openlik loën. Alle geestelike en sedelike waardes moet onder die voete vertrap word". Daar word nie rekening met God gehou nie. Alle grense moet uitgewis word soos dit in die Klerewerkerstryd aan die lig kom (Handelinge 1945 p. 71). „Die Woord van die Here ken geen gelykstelling en vermenging van rasse nie" (p. 188, Handelinge 1946). „Deur Gods genade wil en sal die Gereformeerde Kerk hom hy hierdie Skrifstandpunt hou en bid dat Kerk en volk van SuidAfrika sterk sal staan in die stryd tot eer van God en redding van onsself" (p. 188, Hanelinge 1945).

Dit is opmerklik dat kategories uitgespreek word dat „die Woord van die Here ken geen gelykstelling en vermenging van rasse nie", sonder dat presies aangedui word waar dit uit die Woord van die Here so duidelik blyk. Al grond vir die uitspraak is dat dit 'n beproefde volkstradisie van die Boerevolk" is wat ,hom in hierdie saak nog altyd gehou het aan en laat lei het deur die Bybel" ( $p$. 188, Handelinge 1945).

Met die standpuntstelling teen die Kommunisme, veral soos dit die praktiese lewe in S.A. raak, het die sinode meteens deur die bovermelde kategoriese stellinge die gebied van die rasseproblematiek betree.

\section{ONDERWYS, VREDE EN EVANGELISASIE IN 1945}

Teenoor die verwerping van die vreemde lewens- en wêreldbeskouing is alle aandag vir die bevordering van die eie, veral by die jeug gevra. Die C.N.O. sou vanaf 1945 op elke sinode 'n vername plek inneem. Teen die heersende tendens op die gebied van die 
onderwys by die owerhede $\mathrm{nl}$. om die opvoeding op 'n godsdienstigneutrale en 'n breë Suid-Afrikanisties-engels-georiënteerde lees te skoei, het die sinode gestel die Christelik-nasionale onderwys met die Heidelbergse Kategismus, die Kortbegrip en die Drie Formuliere van Eenheid as leerboeke by die Godsdiensonderrig in die skole en die Moedertaal en eie geskiedenis (Afrikaanse) as grondslag en agtergrond by die algemene onderwys en opvoeding. Die C.N.O. stryd moes nie, so waarsku die sinode, in 'n blote taalstryd ontaard nie. As dit sou gebeur sou „die taal as voertuig dien om vreemde ladings, moderne en onskriftuurlike leringe, in die Afrikaanse skool met die Afrikaanse taal as medium van onderrig in ons volksiel in te dra" (Handelinge 1945, p. 95).

Die Sinode spreek dit as sy begeerte uit dat by vredesluiting ons hoë owerheid sy invloed sal gebruik dat die vrede gefundeer sal word op die groot beginsels van die Christendom en die Woord van God "(Handelinge 1945, p. 103).

Die afval wat veral sedert die aanvang van die oorlog toegeneem het, het die roeping tot evangelisasie dringend gemaak. Op grond van o.a. Luk. $3: 18 ; 8: 1$; Hand. $5: 42$ en Lukas $14: 21$; Matt. $10: 5$ en 6 , word evangelisasie as roeping van die kerk voorgehou. Evangelisasie word onderskei van sending op grond van wat Jesus sê: ,Moenie gaan op pad na die heidene nie.... maar gaan liewer na die verlore skape van die huis van Israel" (Matt. $10: 5,6$ ). Sending is om te gaan na dié wat nog nooit van God gehoor het nie. Evangelisasie is om te gaan na dié wat vroeër die Here geken en gedien het; maar Hom nou nie meer ken of dien nie (Bl. 105, Handelinge 1945).

Voorts is aandag gegee aan sake wat maar altyd weer in die kerklike lewe na vore kom en van belang is vir al die kerke. So is o.a. indringend gehandel oor die eise wat in die Skrif gestel word met betrekking tot predikantstraktemente.

Die Sinode van 1958 gee aandag aan die stemreg van lidmate op gemeentevergaderings en wys dit op grond van Skrif en belydenis af. Die Kerkorde i.v.m. troudienste is weer onder oë gesien in die lig van Skrifgegewens ens.

\section{SINODE 1946 EN EKUMENE}

Reeds in die vooroorlogse jare, so vroeg as Rustenburg 1924, het sinodes erns gemaak met die saamroeping van 'n ekumeniese sinode, d.w.s. ' $n$ sinode van kerke wat een in leer, diens en tug is. Verwikkelinge in die Gereformeerde Kerken in Nederland gedurende die oorlogsjare en veral 1943 en 1944, het so 'n samekoms van kerke dringender gemaak. Die skeuring het veral by die Gereformeerde Kerke 'n behoefte laat ontstaan om ,over het dogmatisch geschilpunt van gedachten te wisselen" (Brief, G. Ch. Aalders aan deputate in sake Ekumeniese Sinode. Handelinge 1946, p. 26). So 'n vergadering sou gedurende 1946 byeengeroep word en die sinode besluit om afgevaardigdes daarheen te stuur. Op die sinode sou gehandel word oor "Die Gereformeerde getuienis in die na-oorlogse wêreld". Dogmatiese en Kerkregtelike vraagstukke sou in die lig van die 
Skrif en belydenis indringend bespreek word. Veral moes die vraag na die "status" (gesag) van so 'n sinode beantwoord word.

Die sinode van 1949 het verslag ontvang van die Ekumeniese Sinode te Grand Rapids gedurende 1945 (Handelinge 1949 bl. 24 e.e.). Hoewel volgens die Skrif kerkverband oor nasionale grense strek (Handelinge 1949 bl. 55) moet „,voorlopig volstaan word met die ekumeniese kerkvergadering" (bl. 56). Daarmee is beslis dat ten spyte van die ideaal 'n ekumeniese sinode in die ware sin van die woord, die tyd vir die instelling van so 'n vergadering nog nie ryp is nie.

\section{DIE SINODES VAN 1952 TOT 1958 OOR DIE RASSEKWESSIE}

Die rassekwessie kom weer op die voorgrond deur 'n rapport oor 'n blanke wat buite-egtelik met 'n gekleurde saamlewe. 'n Besluit van 1920 word aangehaal waarin gekonstateer word dat die huwelik van 'n blanke lid moet met 'n gekleurde beskou word „1) as 'n ernstige vergryp teen die maatskaplike orde wat, onder voorsienige bestel van God, 'n skerpe skeidslyn tussen blankes en gekleurdes getrek het..." (Handelinge 1952, p. 201).

$\mathrm{Na}$ die kategoriese uitsprake van die vorige sinodes oor rassealangelcenthede besluit Sinode 1955 na aanleiding van 'n beskrywingspunt om die apartheidsbeginsel skriftuurlik te ondersoek (Handelinge 1955, p. 141-144).

Die Deputate deur die sinode 1955 benoem „om die apartheidsbeginsel skriftuurlik te ondersoek" rapporteer breedvoerig aan die sinode (Handelinge p. 203).

Die deputate benader die vraagstuk eers in die lig van O.T.gegewens, daarna van N.T.-gegewens.

T.o.v. die O.T.-gegewens is gekonkludeer dat die menslike geslag 'n eenheid is, maar in die eenheid is daar tog ook 'n ryke variasie en differensiasie. Wat God geskei het mag die mens nie saamvoeg nie" (Handelinge 1958, p. 221).

Ten opsigte van die variasie en differensiasie word daar ook op gewys dat ,Nêrens in die Ou Testament is daar enige aanduiding dat vermenging tussen individue of reste van verskillende rasse en volke sondig is nie". Dit kan egter ook nie as sonde bestempel word as 'n ras of volk daarna streef om sy identiteit te bewaar nie, veral nie as daar geen regte van ander aangetas word nie. Trouens dit moet as sonde beskou word as 'n volk sy volksmentaliteit prysgee, daarmee sy eie roeping versaak en die gedagte van verskeidenheid geweld aandoen" (Handelinge 1958, p. 223).

$\mathrm{Na}$ grondige eksegese van relevante gedeeltes uit die N.T. is gekonkludeer: „Die Skrif verstaan onder die kerk die volk van God, die gemeenskap van die gelowiges. Deur die Heilige Gees is die lede van die kerk wedergebore (Joh. 3:5), verseël (Ef. $1: 13$ ), met Christus verenig ( 1 Kor. $12: 3$ ) en 'n woning van God in die Gees (Ef. 2:22). Die kerk is dus wêreldwyd een (vgl. Apost. Gel. Bel.). Hierdie eenheid is op aarde egter nooit te vinde op organisatoriese gebied nie. "Die essensiële eenheid van die kerk is dus nie afhanklik van 'n sigbare organisatoriese eenheid nie" 
(p. 241, Handelinge 1958). Die eenheid van die kerk dra ,dus 'n geestelike karakter, die eenheid van die onsigbare kerk". Die eenheid word nie verbreek deur die feit dat daar verskillende volke en rasse is nie. So vind ons die Christelike Koinonia dwarsoor alle grense van volke en tale, rasse en denominasies heen. Die gelowiges van verskillende rasse is een in Christus. Deur hierdie geestelike eenheid word egter die natuurlike skeidings nie opgehef nie. Die eenheid kom ,nie tot stand deur geforseerde gemeenskap of deur uitwissing van onderskeidinge nie" (p. 241, Handelinge 1958). Op grond van die eenheid in verskeidenheid word gekonkludeer dat dit by die afsonderlike instituering van kerke op grond van ras, volk, taal en kultuurverskille nie in die eerste plek gaan om 'n absolute gebod of verbod nie - die Skrif gee dit ook nie ten opsigte van kerklike instituering nie - maar om wat sal dien tot die meeste nut en voordeel van die kerk van Christus ooreenkomstig die lig van die Skrif vir 'n gegewe historiese situasie en heersende omstandighede (p. 242, Handelinge 1958). Op suiwer skriftuurlike gronde kan geen beswaar teen die begrip van eiesoortige ontwikkeling, ook op kerklike terrein, wees nie, mits die suiwere kerkbegrip op die voorgrond gestel word (p. 242, Handelinge 1958). Onder huidige omstandighede kan so 'n aparte instituering alleen dien tot verryking van die kerklike lewe gesien die ontwikkelingsgaping tussen die blanke en naturel (p. 243, 1958). Aparte instituering is tans dus nie alleen wenslik nie maar noodsaaklik ter bevordering van die saak van Christus, wat nie uitsluit dat daar onderlinge bande kan en moet wees nie (p. 243, 1958). Die bande moet op ekumeniese vlak gesoek word - oor volksgrense heen. „Wanneer die Bantoegemeentes uitgroei tot 'n eie selfstandige kerkverband, moet die ekumeniese verband tussen die kerk onder blankes met wedersydse goedvinde en na wederkerige beraadslaging gereël word" (p. 249, 1958).

Op plaaslike vlak is - hoewel nie prinsipiëel ongeoorloof nie die opname van ,nie-blankes" as lidmate van blanke kerke" afgekeur op voetspoor van wat die Nederlanders in Indonesië gedoen het. Hulle sou voorkom dat die meer ontwikkelde Papoeas na die Nederlandssprekende kerke oorgaan en die Papoeakerke so van hulle beste lede sou beroof en waardeur hulle ,niet tot ontplooiing kunnen komen” (p. 251, 1958). Daar word gekonkludeer „Die nie-blankes kan ook nie bevrediging vind in 'n erediens vir blankes nie, en hulle staan buite die gemeenskap van blankes. Opname van individuele nie-blankes in blanke gemeentes moet dus, in belang van die nie-blankes, nie alleen ontmoedig word nie, maar afgekeur" ( $p$. $251,1958)$.

Daar kan ook geen prinsipiële besware wees teen die bywoning van 'n erediens vir blankes deur nie-blankes nie. Daar is egter ,gewigtige besware wat so ' $n$ bywoning in so ' $n$ veelrassige land soos Suid-Afrika beswaarlik en selfs ondoenlik maak." Dieselfde geld vir die viering van die nagmaal (p. 252 en 253, 1958).

Die kerk het 'n saak van onderrig en opvoeding sowel as toesig ten opsigte van die rasseverhoudinge. Die lidmate moet besiel word met 'n sendingywer deur hulle lerend en biddend te bring tot kennis 
en beoefening van naasteliefde, in woord en daad teenoor heidenvolke (vgl. p. 254,1958 ).

Ten opsigte van die owerheid se rassebeleid en praktyk moet onthou word: „Die kerk se roeping en taak is kerklik. Dit het 'n eie terrein en taak naas en afsonderlik en soewerein onafhanklik van die van die staat. Maar die kerk moet die lig van God se Woord laat skyn en sy wet proklameer oor alle lewensterreine, ook die van die staat en owerheid en sy beleid" (p. 255/6).

In die lig van die prinsipiële uiteensetting is algemene riglyne vir die rasseverhoudinge in die algemeen getrek. Eerstens het 'n Christenvolk wat te midde van heidenvolke (van welke ras ook al) lewe, 'n besondere roeping t.o.v. die kerstening van laasgenoemdes (p. 257, 1958).

Dit kan selfs nodig wees dat in hierdie roepingsvervulling die beskaafde, Christenvolk kan en moet ingryp vanweë stamoorloë, bloedvergieting, rowery ens. om onder die heidene vreedsame toestande te skep deur 'n tydelike oorheersing op grondslag van regverdigheid, veiligheid en beskerming..." (p. 258, 1958). Dit regverdig ook die beginsel van voogdyskap. Opheffing van die voogdyskap vandag in S.A. en Afrika sal chaos tot gevolg hê (p. 263, 1958). Daar moet egter 'n proses van ontvoogding wees. Krenkende rassediskriminasie moet algaande opgehef word namate die ontwikkeling van die Nie-blankes. Voorsiening moet ook gemaak word vir plekke en geleenthede waar die groepe mekaar kan ontmoet ( $p$. 265,1958 ).

Terwille van die roepingsvervulling is dit noodsaaklik dat 'n Christenvolk sy indiwidualiteit handhaaf; „'n vernietiging en verandering van sy indiwidualiteit en verlaging van sy beskawings- en kultuurpeil" beteken ,'n aantasting van die moontlikheid om sy besondere roeping na te leef" (p. 258, 1958).

Eiesoortigheid is egter nie absoluut nie. „Daar is geen ongemengde ras of volk nie, maar die houding teenoor insidentele vermenging mag tog ook bepaal word deur die besondere situasies, aangesien die problecm die uitkoms is van 'n groot kompleks van faktore" (p. 260, 1958).

Alle mense is gelykwaardig omdat almal na die beeld van God geskape is; almal het ook op dieselfde wyse deur hulle sondeskuld die genade van God verbeur. Tog sluit die gelykwaardigheid nie die verskeidenheid uit nie. Daar is groot ongelykheid onder mense ten spyte van die gelykwaardigheid. Niemand sal daaraan dink om die Eerste Minister van 'n land met 'n gewone arbeider gelyk te wil stel nie (p. 261, 1958). Die beginsel van gelykwaardigheid word dus nie per se geweld aangedoen deur die blote handhawing van sosiale, politieke of ekonomiese skeidslyne nie. Waar slegte gesindheid agter apartheid skuil, word dit dodelik vir die bevoogdes en ontaard dit tot 'n onmenslike optrede teenoor hulle (p. 261/2; 1958).

Apartheid is ook terwille van selfbehoud geregverdig. „Enige volk het die reg en verpligting om te verhoed dat sy volksidentiteit verlore gaan as gevolg van 'n oormatige immigrasie van vreemdelinge wat tot verandering van die historiesgeworde rassesamestelling 
en kultuurpatroon geassimileer word" (p. 262, 1958).

Hierdie rapport is onderskryf „vir sover ons insig vandag strek" en vir verdere studie aan deputate opgedra om aan die Sinode van 1961 te rapporteer (p. 270, 1958).

\section{DIE SINODE VAN 1952 EN DIE KERKBEGRIP}

Op kerkregtelike gebied word 'n breedvoerige uiteensetting van die kerkbegrip in die lig van Skrif en belydenis gegee. Verskillende Skrifgedeeltes is in detail ontleed sowel as art. XXVII N.G.B. en Sondag XXI, H.K. Daar is uit die gegewens gekonkludeer dat 1) „In geheel bestaan die kerk of gemeente as een groot eenheid uit alle uitverkorenes of ware gelowiges uit alle eeue en plekke - dit is een heilige algemene Christelike kerk - die liggaam, die bruid van Christus". 2) Hierdie liggaam van Christus ,neem gestalte aan op elke plek op aarde waar daar 'n gemeente gestig word." Christus skep ook die drang in plaaslike gemeentes „om aansluiting met mekaar te soek" (Handelinge 1952, pp. 74/4).

Die Sinode 1955 sluit hierby aan en nadat dogmatiese en Skrifgegewens sowel as kerkregtelike aspekte teen die historiese agtergrond geweeg is, is besluit tot die vasstelling van dic naam: Gereformeerde Kerk in Suid-Afrika.

\section{DIE SINODE VAN 1955 EN DIE EKUMENE, KORRESPONDENSIE}

Voorop staan die verhouding tot „De Gereformeerde Kerken (Onderhoudende art. 31) in Nederland". Vir die bepaling van die verhouding is teruggegryp na die Belydenis. Die feit dat daar onder leiding van dié Kerken oorgegaan is tot aparte kerkinstituering in S.A., het die sinode voor die vraag gestel of die Gereformeerde Kerken (Onderhoudende art. 31) die GKSA ,nie erken as eenders in belydenis en kerkregering nie". 'n Ernstige beroep is op ,die sogenaamde Gereformeerde Kerke in S.A." gedoen om op grond van art. 28 NGB en in ooreenstemming met die Openlike Verklaring, hulle by die GKSA te voeg as kerke wat een is in belydenis en kerkregering" (Handelinge 1955, pp. 40/41).

Daar is ook rapporte van deputate op tafel waarin versoeke tot kontak en medewerking met verskillende ekumeniese bewegings behandel is. Die verhouding tot die liggame en kerke is bepaal deur ,die grondslag daarvan en die band waarmee ledekerke aan die betrokke beweging gebind word". 'n Paar bewegings se belydenisgrondslag is hiermee getoets o.a. die I.C.C.C., die Internasionale Assosiasie van Evangeliste, die Wêreldraad van Kerke e.a.

Daar is slegs t.o.v. die Wêreldraad ' $n$ definitiewe besluit geneem nl. „dat vir die huidige altans die Gereformeerde Kerk nie lid word van die W.C.C. nie" op grond daarvan dat dit , actually permits essentially different interpretations of its doctrinal basis, and thus of the nature of the Christian faith". Voorts gee die Wêreldraad van kerke voor om 'n geloofsgemeenskap te wees, wat dit inderwaarheid nie is nie, omdat kerke met uiteenlopende uitgangspunte byeengebring is (vgl. Handelinge 1955 p. 304, 309). 
Wat die ander bewegings betref is deputate benoem om ' $n$ verdere studie te maak van die I.C.C.C. en die volgende sinode te adviseer i.s. aansluiting (Handelinge 1955, p. 309).

Die term ,korrespondensie" is in die lig van die K.O. sowel as die beslissing van 1945 dat kerkverband nie tot nasionale grense beperk is nie, onder oë geneem. (Hier is nog nie op definitiewe Skrifgronde 'n beroep gedoen nie, Handelinge 1955, pp. 159-165). Daar is gekonkludeer dat korrespondensie in engere sin kerkverband ook oor nasionale grense heen aandui en in ruimere sin dui dit op interkerklike kontak, d.w.s. kontak en selfs samewerking op sekere vlakke met kerke wat nie een is in leer,diens en tug met die Gereformeerde Kerk nie.

Die sinode van 1958 laat die ekumeniese sake en die daarmee samehangende binnelandse kerklike verhoudings, al hoe sterker op die voorgrond tree. In beide gevalle gaan die sinode daarvan uit dat die verhoudinge bepaal moet word in die lig van Skrif en Belydenis. Vir kerklike eenheid is die eis eenheid in leer, diens en tug. Geen eenheid mag nagestreef word ten koste van die waarheid nie.

Wat betref binnelandse kerke wat dieselfde belydenisskrifte as die Gereformeerde Kerk het, is besluit op ,'n interkerklike samespreking” met die oog op „die eenheid van die uitwendige kerk”, wat 'n goddelike eis en opdrag is. „Hieruit vloei die roeping van die kerk voort om dit wat uitmekaar hou, broederlik met mekaar onder oë te sien om sodoende te bring in een kerkverband" (Handelinge 1958, p.p. 79 en 80). Deputate vir so 'n samespreking met binnelandse kerke - die N.G. Kerk en die Herv. Kerk - is deur die sinode benoem. Die samesprekings duur vandag nog voort en oor die ecrste besprekingspunt $\mathrm{nl}$. die kerkbegrip, is tans nog geen finaliteit bereik nie.... na 20 jaar!

\section{DIE SINODE VAN 1961 OOR RASSEAANGELEENTHEDE}

Op dié sinode dien 'n rapport oor rasseaangeleenthede waarin die rapport van 1958 net bygewerk is. Basies is tot dieselfde konklusies as in 1958 gekom. Die konklusies is ook nader uit Skrif en belydenis gemotiveer (vgl. Handelinge 1961, p. 108-114). Daar is ook aanbeveel dat 'n verdere eksegetiese studie van die begrip voogdyskap gemaak moet word. Voorts moet die verband tussen die bestaande rasse en die seuns van Noag bestudeer word. Ook moet ondersoek ingestel word na die landsbeleid en praktyke m.b.t. rasseaangeleenthede in die lig van die bevindinge van die rapport. Die besluite en praktyke van die Geref. Kerk m.b.t. rasseaangeleenthede moet ook getoets word aan die beginsels soos in die rapport geformuleer (p. 115, 1961). Die rasseverhoudinge word op die sinode verder geaksentueer deur briewe van die Gereformeerde Kerken in Nederland sowel as die Christian Reformed Church of America, waarin die sinode om 'n uitspraak en oordeel oor apartheid gevra is: Die versoeke is op hierdie stadium nog in 'n uiters simpatieke en beskeie gees gerig.

Met groot erns is voortgegaan om, soos op voorgaande sinodes, 
vorige sinodebesluite in kerklike praktyke die Skrif en belydenis te toets aan die hand van beswaarskrifte en beskrywingspunte.

\section{DIE SINODE VAN 1961 OOR DIE DOOP EN LITURGIESE FORMULIERE}

So dien daar 'n rapport deur deputate oor die vertraging van die doop. Die betekenis van die doop is by vernuwing uit Skrif en belydenis na vore gebring. Die belydenis art. XXXIV en Gen. 17:7 is deeglik benadruk om sodoende te beklemtoon dat dit noodsaaklik is om die doop aan verbondskinders so gou as moontlik te bedien (vgl. p. 133, 1961).

Daar is op die sinode van 1961 ook begin met die studie ter hersiening en/of verkorting van die liturgiese formuliere in samewerking met die N.G. en Hervormde Kerke.

\section{SINODE 1964 EN DIE HERSIENING VAN DIE KERKORDE}

Die hersiening van die K.O. het in 1952 op die sinodetafel gekom via ' $n$ skrywe van die Gereformeerde Kerken in Nederland wat medewerking in hulle hersiening van die K.O. gevra het. Toe is verklaar dat daar by die Geref. Kerk geen behoefte aan 'n hersiening is nie, maar deputate is benoem om daarop in te gaan. Die gevolg was dat die Sinodes 1955 en 1958 op 'n hersiening besluit het op voorwaarde dat die essensie en selfs die nommering van die artikels van die D.K.O. so veel as moontlik behou moet word. Die werk het in 1964 gereed gekom en is deur die sinode aanvaar. Die revisie het weinig verandering aan die bestaande K.O. aangebring. Hoewel die revisie afgehandel is, het daar tog enkele artikels soos 21 en 70 nog nadere aandag vereis. Ook is daar op volgende sinodes telkemale weer teruggekom of op die beginsels begrepe in artikels van die K.O. of op die implementering daarvan. So het die sinodes van $1967,70,73$ en 76 veral gekonsentreer op die artikels rondom die amp $(4,12,13$ en 14 ens.).

Die sinode is verder oorheers deur beskrywingspunte en beswaarskrifte waarin die Skriftuurlike grondslae van die K.O. en sekere sinodebesluite deeglik getoets is.

\section{DIE SINODE VAN 1964 OOR EKUMENE, EENHEID VAN DIE KERK EN ALGEMENE SINODE}

Ekumeniese sake het verdere aandag gekry veral uit die oogpunt van die eenheid van die kerk. Die eenheid is benader vanuit die veelheid van 1) nasionale kerke en 2) verskillende kerkgemeenskappe. Volgens die Skrif is die kerk van die Here een en daarom moet die eenheid ook by die instituering van die kerk aan die lig kom. Waar daar verskillende kerkgemeenskappe onder dieselfde volk en dieselfde land uitmekaar leef moet daar samesprekinge wees wat tot herstel van die gebroke eenheid moet meewerk (vgl. wat reeds besluit is in 1958 en die deputate wat benoem is met die oog op sodanige samesprekinge). Oor die landsgrense en volksgrense 
heen moet die kerke wat een in leer, diens en tug is die eenheid ook organisatories beleef.

Op grond van hierdie prinsipes is besluit om ,'n werklike ekumeniese sinode van 'n verskeidenheid van Gereformeerde Kerke in S.A. met dieselfde konfessie en kerkregering saam te roep."

Dié Sinode het in 1965 saamgekom, maar daar is op die vergadering besluit dat die naam ekumeniese sinode nie paslik is nie omdat die Europese en Amerikaanse Geref. Kerke ontbreek het en daar is gepraat van 'n „Algemene Sinode van Gereformeerde kerke in Suidelike Afrika".

Die saamroeping van hierdie sinode het die prinsipiële besinning van vorige sinodes oor rasseaangeleenthede gekoppel aan die praktyk. Die beginsel is daarmee op Geref. Kerklike erf in die praktyk deurgetrek; terwyl daar nog steeds op die sinode 1964 en daarna tot op die hede, verder prinsipieel besin word.

'n Tweede praktiese uitvloeisel van die prinsipiële besinning deur die na-oorlogse jare was die besondere aandag wat die sending voortgaande gekry het. Aparte kerkgroepe is onder die verskillende volkere geïnstitueer en die kerke onder die verskillende volke het as selfstandige kerke eie meerdere vergaderinge in die lewe geroep. Die Geref. Kerk in S.A. het ook vroeg in die vyftiger jare reeds 'n teologiese skool vir die jong kerke opgerig en beman tot tyd en wyl hulle self die kragte daartoe het.

\section{DIE GKSA EN KORRESPONDENSIE MET DIE GK NEDERLAND}

Hoewel die korrespondensie met die Geref. Kerke in Nederland direk na die oorlog veral 'n simpatieke meelewing met die kerke in die smartlike kerkskeuring wat hulle in 1944 beleef het was, het daar tog stelselmatig spanning tussen die kerke begin oplaai. Van die Gereformeerde kerke se kant is alhoemeer kritiese vrae oor die apartheidsbeleid en die instemming van die Gereformeerde Kerk in S.A. daarmee, gestel. Van die Gereformeerde Kerk in S.A. se kant het daar sedert 1955 bedenkinge oor die kerkregtelike ontwikkeling veral soos geopenbaar in die Hersiene Kerkorde, ontstaan. Maar op die sinode van 1967 kom die verontrusting aan die lig ook oor wendinge op leerstellige gebied. Die Partikuliere Sinode O.V.S. en Natal het die Nasionale Sinode gevra ,om kragtens korrespondensie met genoemde kerke hom rekenskap te gee van sy houding teenoor genoemde kerke na aanleiding van art. 85 K.O." (Handelinge 1967, p. 429). Die Sinode ag dit toe nog nie nodig om rekenskap te gee nie, want - soos prof. Ridderbos verduidelik het - dit het toe nog gegaan oor teologiese dispute en nie oor offisiële besluite van die Gereformeerde Kerken in Nederland nie.

Die Sinode van 1970 stel egter vas „dat die kerklike en teologiese situasie in Nederland nou, om die minste daarvan te sê, verward is" (Handelinge 1970, p. 81, 82). Sake wat die broederlike band met die kerke kan skaad is: ,a) Gesamentlike dienste met Nederlandse Hervormde Kerk. b) Liturgie en nieuwe kerkboek. c) Wêreldraad van kerke. d) Prediking. e) Leer en teologie."

Die saak het 'n verdere verloop op die Sinode van 1973 gekry 
toe die Partikuliere Sinode O.V.S. en Natal in 'n beskrywingspunt gevra het dat die Gereformeerde Kerken in Nederland vermaan en tereggewys word oor die ontwikkeling op leerstellige en kerkregtelike gebied. Die Sinode van Sneek 1969/70 het besware oor die propagering van afwykinge in die leer van professore aan die V.U. en Theologische Hoogeschool te Kampen, sowel as van predikante ontwyk en nie opgetree nie. Dié houding van die Gereformeerde Kerken in Nederland het ,die eenheid in belydenis daardeur in gedrang gebring".

Hierdie versoek is gemotiveer deur te wys op art. 51 K.O. wat inhou dat kragtens die korrespondensie die Gereformeerde Kerken in Nederland ,, as een met ons in leer, diens en tug" is (p. 33, Handelinge 1973). Die eenheid kan nie meer aanvaar word nie, want pennevrugte van professore en predikante het ,gedurende die afgelope jare meer en meer aan die lig gebring dat ander opvattinge oor die gesag van die Heilige Skrif en die leer, as die vervat in die belydenisskrifte, gangbaar geword het en openlik verkondig word in die kerk" (p. 34, 1973). Hierdie propagering van afwykende gevoelens word volhardend geduld ten spyte van die beloftes wat die betrokkenes in die ondertekeningsformuliere vir predikante onderskryf het. Die tug is nagelaat, terwyl die Skrif eis dat dit nie toegelaat mag word dat 'n vreemde leer in kerk verkondig word nie (1 Tim. $6: 3-5$ ).

Die Sinode het gevolg gegee ,aan die beskrywingspunt van die part. sinode O.V.S. en Natal om ,die nodige teregwysing en vermaning te rig aan die Geref. Kerken in Nederland" deur middel van twee deputate (p. 81, 1973). Die opdrag is uitgevoer gedurende Maart 1974. Die vermaning het nie veel uitgerig tot bekering nie en die deputate moes aan die Sinode 1976 rapporteer dat die Sinode van Haarlem 1974 se houding sodanig was dat gekonstateer moet word ,dat daar geen eenheid in leer, diens en tug meer is nie en dat derhalwe verklaar word dat die korrespondensie met die G.K.N. ook formeel opgehef word" (p. 249, 1976). Hierdie rapport is aanvaar en die korrespondensie tussen die GKSA en GKN vir langer as 'n eeu is verbreek.

Referaat gelewer by die S.A. Kerkhistoriese Werkgemeenskap, Stellenbosh 1979. 